\title{
STRATEGI PEMBELAJARAN BAGI ANAK BERKEBUTUHAN KHUSUS DI SLB
}

\author{
Oki Dermawan \\ Institut Agama Islam Negeri Raden Intan Bandar Lampung \\ email: okidermawan76@yahoo.co.id
}

\begin{abstract}
Abstrak
Anak Berkebutuhan Khusus adalah istilah lain untuk menggantikan kata "Anak Luar Biasa, yang menandakan adanya kelainan khusus. Anak berkebutuhan khusus mempunyai karakteristik yang berbeda antara yang satu dengan lainnya. Karakteristik dan hambatan yang dimiliki membuat anak berkebutuhan khusus memerlukan pelayanan pendidikan khusus yang disesuaikan dengan kemampuan dan potensi mereka. Anak berkebutuhan khusus memiliki kelainan fisik, emosional, mental, intelektual, dan/atau sosial, baik dalam tingkat keterbatasan maupun kelebihan. Demi suksesnya perluasan dan pemerataan pelayanan pendidikan bagi Anak berkebutuhan khusus di SLB PKK Bandar Lampung, penulis menyarankan agar pihak sekolah proaktif mensosialisasikan keberadaan pendidikan khusus ini kepada masyarakat.
\end{abstract}

Kata kunci: Anak Berkebutuhan Khusus, strategi pembelajaran

\section{Abstract}

Special need children is used to replace extraordinary children indicating specific abnormalities had. Special need children have different characteristics from one another. The characteristics and constraints had make them require special education services adapted with their abilities and potential. Special need children have physical, emotional, mental, intellectual, or or social weakness and strength. Proposing expansion and equalization of educational services for special need children in SLB PKK Bandar Lampung, school should be pro-active in socializing the existence of special education.

Keywords : special need children, student with special need strategic.

\section{PENDAHULUAN}

Pada dasarnya setiap anak berpotensi mengalami problema dalam belajar, hanya saja problema tersebut ada yang ringan dan tidak memerlukan perhatian khusus dari orang lain karena dapat diatasi sendiri oleh yang bersangkutan dan ada juga yang problem belajarnya cukup berat sehingga perlu mendapatkan perhatian dan bantuan dari orang lain. Anak luar biasa atau disebut sebagai anak berkebutuhan khusus (children with special needs), memang tidak selalu mengalami problem dalam belajar. Namun, ketika mereka diinteraksikan bersama-sama dengan anak-anak sebaya lainnya dalam sistem pendidikan regular, ada hal-hal tertentu yang harus mendapatkan perhatian khusus dari guru dan sekolah untuk mendapatkan hasil belajar yang optimal. 
Pembelajaran untuk anak berkebutuhan khusus (student with special needs) membutuhkan suatu strategi tersendiri sesuai dengan kebutuhan masing-masing. Dalam penyusunan program pembelajaran untuk setiap bidang studi hendaknya guru kelas sudah memiliki data pribadi setiap peserta didiknya. Data pribadi yakni berkaitan dengan karateristik spesifik, kemampuan dan kelemahanya, kompetensi yang dimiliki, dan tingkat perkembanganya. Karakteristik spesifik student with special needs pada umumnya berkaitan dengan tingkat perkembangan fungsional.

Karaktristik spesifik tersebut meliputi tingkat perkembangan sensori motor, kognitif, kemampuan berbahasa, ketrampilan diri, konsep diri, kemampuan berinteraksi sosial serta kreativitasnya.

Untuk mengetahui secara jelas tentang karakteristik dari setiap siswa seorang guru terlebih dahulu melakukan skrining atau asesmen agar mengetahui secara jelas mengenai kompetensi diri peserta didik bersangkutan. Tujuannya agar saat memprogramkan pembelajaran sudah dipikirkan mengenbai bentuk strategi pembelajaran yang dianggap cocok. Asesmen di sini adalah proses kegiatan untuk mengetahui kemampuan dan kelemahan setiap peserta didik dalam segi perkembangan kognitif dan perkembangan sosial, melalui pengamatan yang sensitif. Kegiatan ini biasanya memerlukan penggunaan instrumen khusus secara baku atau dibuat sendiri oleh guru kelas.

Model pembelajaran terhadap peserta didik berkebutuhan khusus yang di persiapkan oleh guru di sekolah, ditujukan agar peserta didik mampu berinteraksi terhadap lingkungan sosial. Pembelajaran tersebut disusun secara khusus melalui penggalian kemampuan diri peserta didik yang didasarkan pada kurikulum berbasis kompetensi. Kompetensi ini terdiri atas empat ranah yang perlu diukur meliputi kompetensi fisik, kompetensi afektif, kompetensi sehari- hari dan kompetensi akademik. ${ }^{1}$ Penelitiam ini akan membahas mengenai "Strategi Pembelajaran bagi Anak Berkebutuhan Khusus di SLB PKK Sukarame Bandar Lampung"

Rumusan masalah yang diajukan adalah Apakah definisi dari anak berkebutuhan khusus?Bagaimana jenis dan karakteristik anak berkebutuhan khusus? Bagaimana strategi pembelajaran bagi anak berkebutuhan khusus di SLB PKK Sukarame Bandar Lampung? Adapun tujuan dari penelitian ini adalah menjelaskan definisi dari anak berkebutuhan khusus, mengidentifikasi jenis dan karakteristik anak berkebutuhan khusus, dan menjelaskan strategi pembelajaran bagi anak berkebutuhan khusus.

Anak berkebutuhan khusus (Heward) adalah anak dengan karakteristik khusus yang berbeda dengan anak pada umumnya tanpa selalu menunjukkan pada ketidakmampuan mental, emosi atau fisik. ${ }^{2}$ Anak dengan kebutuhan khusus adalah anak yang secara signifikan mengalami kelainan atau penyimpangan (fisik, mentalintelektual, sosial, dan emosional) dalam proses pertumbuhkembangannya dibandingkan dengan anak-anak lain yang seusia sehingga memerlukan pelayanan pendidikan khusus. ${ }^{3}$

Anak Berkebutuhan Khusus (ABK) merupakan istilah lain untuk menggantikan kata "Anak Luar Biasa (ALB)" yang menandakan adanya kelainan khusus. Anak berkebutuhan khusus mempunyai karakteristik yang berbeda antara yang satu dengan yang lainnya. Karena karakteristik dan hambatan yang dimilki, ABK memerlukan bentuk pelayanan pendidikan

\footnotetext{
${ }^{1}$ Greenspan, 1997: 131, dalam smith et al., 2002: 95
}

http://id.wikipedia.org/wiki/Anak_berkebutuha n_khusus

http://bintangbangsaku.com/artikel/tag/anakberkebutuhan-khusus 


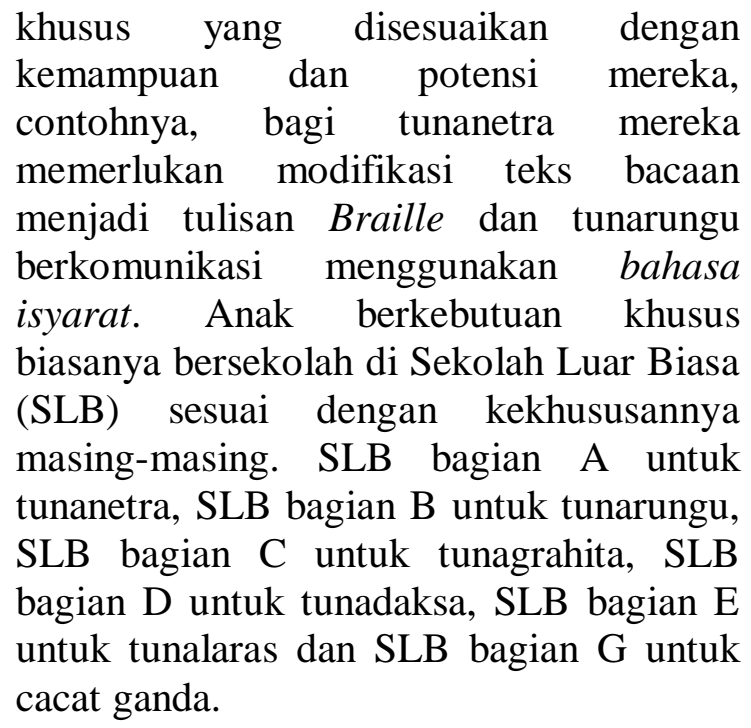

\section{a. Tunagrahita (mental retardation)}

Anak berkebutuhan khusus yang paling banyak mendapat perhatian guru antara lain $^{4}$ anak tunagrahita (mental retardation). Ada beberapa definisi dari tunagrahita, antara lain:

1. American Association on Mental
Deficiency (AAMD) dalam B3PTKSM, mendefinisikan retardasi mental/tunagrahita sebagai kelainan yang meliputi fungsi intelektual umum di bawah rata-rata (subaverage), yaitu IQ 84 ke bawah berdasarkan tes individual; yang muncul sebelum usia 16 tahun; dan menunjukkan hambatan dalam perilaku adaptif.

2. Japan League for Mentally Retarded dalam B3PTKSM, mendefinisikan retardasi mental/ tunagrahita ialah fungsi intelektualnya lamban, yaitu IQ 70 ke bawah berdasarkan tes intelegensi baku; kekurangan dalam perilaku adaptif; dan terjadi pada masa perkembangan, yaitu antara masa konsepsi hingga usia 18 tahun.

3. The New Zealand Society for the Intellectually Handicapped menyatakan tentang tunagrahita adalah bahwa seseorang dikatakan

${ }^{4}$ Kauffman dan Hallahan. Hand Book of Special Education, New York: Routledge, 2005, h.28-45. tunagrahita apabila kecerdasannya jelas-jelas di bawah rata-rata dan berlangsung pada masa perkembangan serta terhambat dalam adaptasi tingkah laku terhadap lingkungan sosialnya.

Definisi tunagrahita yang dipublikasikan oleh American Association on Mental Retardation (AAMR). Di awal tahun 60-an, tunagrahita merujuk pada keterbatasan fungsi intelektual umum dan keterbatasan pada keterampilan adaptif. Keterampilan adaptif mencakup area : komunikasi, merawat diri, home living, keterampilan sosial, bermasyarakat, mengontrol diri, functional academics, waktu luang, dan kerja. Menurut definisi ini, ketunagrahitaan muncul sebelum usia 18 tahun.

Menurut WHO seorang tunagrahita memiliki dua hal yang esensial yaitu fungsi intelektual secara nyata di bawah rata-rata dan adanya ketidakmampuan dalam menyesuaikan diri dengan norma dan tututan yang berlaku dalam masyarakat. ${ }^{5}$

Adapun cara mengidentifikasi seorang anak termasuk tunagrahita yaitu melalui beberapa indikasi sebagai berikut:

1. Penampilan fisik tidak seimbang, misalnya kepala terlalu kecil/besar,

2. Tidak dapat mengurus diri sendiri sesuai usia,

3. Perkembangan bicara atau bahasa terlambat,

4. Tidak ada/kurang sekali perhatiannya terhadap lingkungan (pandangan kosong),

5. Koordinasi gerakan kurang (gerakan sering tidak terkendali),

6. Sering keluar ludah (cairan) dari mulut (ngiler).

\footnotetext{
${ }^{5}$ http://bintangbangsaku.com/artikel/tag/anakberkebutuhan-khusus
} 


\section{b. Tunalaras (Emotional or behavioral disorder)}

Tunalaras adalah individu yang mengalami hambatan dalam mengendalikan emosi dan kontrol sosial. individu tunalaras biasanya menunjukan prilaku menyimpang yang tidak sesuai dengan norma dan aturan yang berlaku disekitarnya. Tunalaras dapat disebabkan karena faktor internal dan faktor eksternal yaitu pengaruh dari lingkungan sekitar.

Menurut Eli M. Bower, anak dengan hambatan emosional atau kaelainan perilaku, apabila menunjukkan adanya satu atau lebih dari lima komponen berikut:

1. Tidak mampu belajar bukan disebabkan karena faktor intelektual, sensori atau kesehatan.

2. Tidak mampu untuk melakukan hubungan baik dengan teman-teman dan guru-guru.

3. Bertingkah laku atau berperasaan tidak pada tempatnya.

4. Secara umum mereka selalu dalam keadaan pervasive dan tidak menggembirakan atau depresi.

5. Bertendensi ke rah symptoms fisik: merasa sakit atau ketakutan berkaitan dengan orang atau permasalahan di sekolah.

Anak yang mengalami gangguan emosi dan perilaku juga bisa diidentifikasi melalui indikasi berikut: ${ }^{6}$

1. Bersikap membangkang,

2. Mudah terangsang emosinya,

3. Sering melakukan tindakan aggresif,

4. Sering bertindak melanggar norma social/norma susila/hukum.

\section{c. Tunarungu Wicara (Communication disorder and deafness)}

Tunarungu adalah individu yang memiliki hambatan dalam pendengaran baik permanen maupun tidak permanen.

\footnotetext{
${ }^{6}$ http://bintangbangsaku.com/artikel/tag/anakberkebutuhan-khusus
}

Klasifikasi tunarungu berdasarkan tingkat gangguan pendengaran adalah: ${ }^{7}$

1. Gangguan pendengaran sangat ringan $(27-40 \mathrm{~dB})$,

2. Gangguan pendengaran ringan(41$55 \mathrm{~dB}$ ),

3. Gangguan pendengaran sedang(56$70 \mathrm{~dB})$

4. Gangguan pendengaran berat(71$90 \mathrm{~dB})$,

5. Gangguan pendengaran ekstrim/tuli(di atas 91dB).

Karena memiliki hambatan dalam pendengaran individu tunarungu memiliki hambatan dalam berbicara sehingga mereka biasa disebut tunawicara. Cara berkomunikasi dengan individu menggunakan bahasa isyarat, untuk abjad jari telah dipatenkan secara internasional sedangkan untuk isyarat bahasa berbeda-beda di setiap negara. saat ini dibeberapa sekolah sedang dikembangkan komunikasi total yaitu cara berkomunikasi dengan melibatkan bahasa verbal, bahasa isyarat dan bahasa tubuh. Individu tunarungu cenderung kesulitan dalam memahami konsep dari sesuatu yang abstrak.

Berikut identifikasi anak yang mengalami gangguan pendengaran ${ }^{8}$ :

1. Tidak mampu mendengar,

2. Terlambat perkembangan bahasa,

3. Sering menggunakan isyarat dalam berkomunikasi,

4. Kurang/tidak tanggap bila diajak bicara,

5. Ucapan kata tidak jelas,

6. Kualitas suara aneh/monoton,

7. Sering memiringkan kepala dalam usaha mendengar,

8. Banyak perhatian terhadap getaran,

9. Keluar nanah dari kedua telinga,

10. Terdapat kelainan organis telinga.

http://id.wikipedia.org/wiki/Anak_berkebutuhan_k husus

${ }^{8} \mathrm{http}$ ///bintangbangsaku.com/artikel/tag/anakberkebutuhan-khusus 
Nilai standarnya 7.

\section{d. Tunanetra (Partially seing and legally blind)}

Tunanetra adalah individu yang memiliki hambatan dalam penglihatan. tunanetra dapat diklasifikasikan kedalam dua golongan yaitu: buta total (Blind) dan low vision. Definisi Tunanetra menurut Kaufman \& Hallahan adalah individu yang memiliki lemah penglihatan atau akurasi penglihatan kurang dari 6/60 setelah dikoreksi atau tidak lagi memiliki penglihatan. Karena tunanetra memiliki keterbataan dalam indra penglihatan maka proses pembelajaran menekankan pada alat indra yang lain yaitu indra peraba dan indra pendengaran. Oleh karena itu prinsip yang harus diperhatikan dalam memberikan pengajaran kepada individu tunanetra adalah media yang digunakan harus bersifat taktual dan bersuara, contohnya adalah penggunaan tulisan braille, gambar timbul, benda model dan benda nyata. sedangkan media yang bersuara adalah tape recorder dan peranti lunak JAWS. Untuk membantu tunanetra beraktivitas di sekolah luar biasa mereka belajar mengenai Orientasi dan Mobilitas. Orientasi dan Mobilitas diantaranya mempelajari bagaimana tunanetra mengetahui tempat dan arah serta bagaimana menggunakan tongkat putih (tongkat khusus tunanetra yang terbuat dari alumunium).

Berikut identifikasi anak yang mengalami gangguan penglihatan ${ }^{9}$ :

1. Tidak mampu melihat,

2. Tidak mampu mengenali orang pada jarak 6 meter,

3. Kerusakan nyata pada kedua bola mata,

4. Sering meraba-raba/tersandung waktu berjalan,

\footnotetext{
${ }^{9}$ http://bintangbangsaku.com/artikel/tag/anakberkebutuhan-khusus
}

5. Mengalami kesulitan mengambil benda kecil di dekatnya,

6. Bagian bola mata yang hitam berwarna keruh/besisik/kering,

7. Mata bergoyang terus.

Nilai standarnya adalah 6 , artinya bila anak mengalami minimal 6 gejala di atas, maka anak termasuk tunanetra.

\section{e. Tunadaksa (physical disability)}

Tunadaksa adalah individu yang memiliki gangguan gerak yang disebabkan oleh kelainan neuromuskular dan struktur tulang yang bersifat bawaan, sakit atau akibat kecelakaan, termasuk celebral palsy, amputasi, polio, dan lumpuh. Tingkat gangguan pada tunadaksa adalah ringan yaitu memiliki keterbatasan dalam melakukan aktivitas fisik tetap masih dapat ditingkatkan melalui terapi, sedang yaitu memilki keterbatasan motorik dan mengalami gangguan koordinasi sensorik, berat yaitu memiliki keterbatasan total dalam gerakan fisik dan tidak mampu mengontrol gerakan fisik. Berikut identifikasi anak yang mengalami kelainan anggota tubuh tubuh/gerak tubuh: ${ }^{10}$

1. Anggota gerak tubuh kaku atau lemah/lumpuh,

2. Kesulitan dalam gerakan (tidak sempurna, tidak lentur/tidak terkendali),

3. Terdapat bagian anggota gerak yang tidak lengkap/tidak sempurna/lebih kecil dari biasa,

4. Terdapat cacat pada alat gerak,

5. Jari tangan kaku dan tidak dapat menggenggam,

6. Kesulitan pada saat berdiri/berjalan/duduk, dan menunjukkan sikap tubuh tidak normal,

7. Hiperaktif/tidak dapat tenang. Nilai standarnya 5.

\footnotetext{
${ }^{10} \mathrm{http}: / /$ bintangbangsaku.com/artikel/tag/anakberkebutuhan-khusus
} 


\section{f. Tunaganda (Multiple handicapped)}

Menurut Johnston \& Magrab, tunaganda adalah mereka yang mempunyai kelainan perkembangan mencakup kelompok yang mempunyai hambatan-hambatan perkembangan neurologis yang disebabkan oleh satu atau dua kombinasi kelainan dalam kemampuan seperti intelegensi, gerak, bahasa, atau hubungan pribadi di masyarakat. Walker berpendapat mengenai tunaganda sebagai berikut:

1. Seseorang dengan dua hambatan yang masing-masing memerlukan layanan-layanan pendidikan khusus.

2. Seseorang dengan hambatanhambatan ganda yang memerlukan layanan teknologi.

3. Seseorang dengan hambatanhambatan yang memerlukan modifikasi khusus.

\section{g. Kesulitan Belajar (Learning disabilities)}

Anak dengan kesulitan belajar adalah individu yang memiliki gangguan pada satu atau lebih kemampuan dasar psikologis yang mencakup pemahaman dan penggunaan bahasa, berbicara dan menulis yang dapat memengaruhi kemampuan berfikir, membaca, berhitung, berbicara yang disebabkan karena gangguan persepsi, brain injury, disfungsi minimal otak, dislexia, dan afasia perkembangan. individu kesulitan belajar memiliki IQ rata-rata atau diatas rata-rata, mengalami gangguan motorik persepsi-motorik, gangguan koordinasi gerak, gangguan orientasi arah dan ruang dan keterlambatan perkembangan konsep. Berikut adalah karakteristik anak yang mengalami kesulitan belajar dalam membaca, menulis dan berhitung ${ }^{11}$ :

\footnotetext{
${ }^{11} \mathrm{http}: / /$ bintangbangsaku.com/artikel/tag/anakberkebutuhan-khusus
}

1. Anak yang mengalami kesulitan membaca (disleksia)

2. Perkembangan kemampuan membaca terlambat,

3. Kemampuan memahami isi bacaan rendah,

4. Kalau membaca sering banyak kesalahan

Nilai standarnya 3.

1. Anak yang mengalami kesulitan menulis (disgrafia)

2. Kalau menyalin tulisan sering terlambat selesai,

3. Sering salah menulis huruf $b$ dengan $\mathrm{p}, \mathrm{p}$ dengan $\mathrm{q}, \mathrm{v}$ dengan $\mathrm{u}, 2$ dengan 5, 6 dengan 9, dan sebagainya,

4. Hasil tulisannya jelek dan tidak terbaca,

5. Tulisannya banyak salah atau terbalik atau huruf hilang,

6. Sulit menulis dengan lurus pada kertas tak bergaris.

Nilai standarnya 4.

1. Anak yang mengalami kesulitan berhitung (diskalkula)

2. Sulit membedakan tanda-tanda:,+- , $\mathrm{x},:,>,<,=$

3. Sulit mengoperasikan hitungan atau bilangan,

4. Sering salah membilang dengan urut,

5. Sering salah membedakan angka 9 dengan 6; 17 dengan 71, 2 dengan 5, 3 dengan 8 , dan sebagainya,

6. Sulit membedakan bangun-bangun geometri.

Nilai standarnya 4.

h. Anak Berbakat (Giftedness and special talents)

Menurut Milgram, R.M (1991:10), anak berbakat adalah mereka yang mempunyai skor IQ 140 atau lebih diukur dengan instrument Stanford Binet (Terman), mempunyai kreativitas tinggi (Guilford), kemampuan memimpin dan kemampuan dalam seni drama, seni tari dan seni rupa (Marlan). Anak berbakat mempunyai empat kategori, sebagai berikut: 
1. Mempunyai kemampuan intelektual atau intelegensi yang menyeluruh, mengacu pada kemampuan berpikir secara abstrak dan mampu memecahkan masalah secara sistematis dan masuk akal.

2. Kemampuan intelektual khusus, mengacu pada kemampuan yang berbeda dalam matematika, bahasa asing, music, atau ilmu pengetahuan alam.

3. Berpikir kreatif atau berpikir murni menyeluruh. Pada umumnya mampu berpikir untuk menyelesaikan masalah yang tidak umum dan memerlukan pemikiran tinggi.

4. Mempunyai bakat kreatif khusus, bersifat orisinil dan berbeda dengan yang lain.

Dari keempat kategori di atas, maka anak berbakat adalah mereka yang mempunyai kemampuankemampuan yang unggul dalam segi intelektual, teknik, estetika, social, fisik (Freemen), akademik, psikomotor dan psikososial. Berikut identifikasi anak berbakat atau anak yang memilki kecerdasan dan kemampuan yang luar biasa $^{12}$

1. Membaca pada usia lebih muda,

2. Membaca lebih cepat dan lebih banyak,

3. Memiliki perbendaharaan kata yang luas,

4. Mempunyai rasa ingin tahu yang kuat,

5. Mempunayi minat yang luas, juga terhadap masalah orang dewasa,

6. Mempunyai inisiatif dan dapat berkeja sendiri,

7. Menunjukkan keaslian (orisinalitas) dalam ungkapan verbal,

8. Memberi jawaban-jawaban yang baik,

9. Dapat memberikan banyak gagasan,

\footnotetext{
${ }^{12} \mathrm{http}: / /$ bintangbangsaku.com/artikel/tag/anakberkebutuhan-khusus
}

10. Luwes dalam berpikir, Terbuka terhadap rangsangan-rangsangan dari

11. lingkungan, Mempunyai pengamatan yang tajam, dapat berkonsentrasi untuk jangka waktu panjang, terutama terhadap tugas atau bidang yang diminati,

12. Berpikir kritis, juga terhadap diri sendiri,

13. Senang mencoba hal-hal baru,

14. Mempunyai daya abstraksi, konseptualisasi, dan sintesis yang tinggi,

15. Senang terhadap kegiatan intelektual dan pemecahan masalah,

16. Cepat menangkap hubungan sebabakibat,

17. Berperilaku terarah pada tujuan,

18. Mempunyai daya imajinasi yang kuat,

19. Mempunyai banyak kegemaran (hobi),

\section{i. Anak Autistik}

Nilai standarnya 18. Autism Syndrome merupakan kelainan yang disebabkan adanya hambatan pada ketidakmampuan berbahasa yang diakibatkan oleh kerusakan pada otak. Gejala-gejala autism menurut Delay \& Deinaker dan Marholin \& Philips antara lain:

1. Senang tidur bermalas-malasan atau duduk menyendiri dengan tampang acuh, muka pucat, dan mata sayu dan selalu memandang ke bawah.

2. Selalu diam sepanjang waktu.

3. Jika ada pertanyaan terhadapnya, jawabannya sangat pelan dengan nada monoton, kemudian dengan suara yang aneh akan menceritakan dirinya dengan beberapa kata kemudian diam menyendiri lagi.

4. Tidak pernah bertanya, tidak menunjukkan rasa takut dan tidak menyenangi sekelilingnya.

Tidak tampak ceria. 
a. Tidak peduli terhadap lingkungannya, kecuali terhadap benda yang disukainya.

b. Secara umum anak autis mengalami kelainan dalam berbicara, kelainan fungsi saraf dan intelektual, Hal tersebut dapat terlihat dengan adanya keganjilan perilaku dan ketidakmampuan berinteraksi dengan lingkungan sekitarnya.

\section{j. Hyperactive (Attention Deficit Disorder with Hyperactive)}

Hyperactive bukan merupakan penyakit tetapi suatu gejala atau symptoms. (Batshaw \& Perret, 1986: 261).symptoms terjadi disebabkan oleh factor-faktor brain damage, an emotional disturbance, a hearing deficit or mental retardaction. Dewasa ini banyak kalangan medis masih menyebut anak hiperaktif dengan istilah attention deficit disorder (ADHD)

\section{Strategi Pembelajaran Bagi Anak Berkebutuhan Khusus}

Anak berkebutuhan khusus (ABK) ini ada dua kelompok, yaitu: $\mathrm{ABK}$ temporer (sementara) dan permanen (tetap). Adapun yang termasuk kategori ABK temporer meliputi: anak-anak yang berada di lapisan strata sosial ekonomi yang paling bawah, anak-anak jalanan (anjal), anak-anak korban bencana alam, anak-anak di daerah perbatasan dan di pulau terpencil, serta anak-anak yang menjadi korban HIV-AIDS. Sedangkan yang termasuk kategori ABK permanen adalah anak-anak tunanetra, tunarungu, tunagrahita, tunadaksa, tunalaras, Autis, ADHD (Attention Deficiency and Hiperactivity Disorders), Anak Berkesulitan Belajar, Anak berbakat dan sangat cerdas (Gifted), dan lain-lain.

Untuk menangani ABK tersebut dalam setting pendidikan inklusif di Indonesia, tentu memerlukan strategi khusus. Pendidikan inklusi mempunyai pengertian yang beragam. Stainback dan Stainback mengemukakan bahwa: sekolah inklusi ${ }^{13}$ adalah sekolah yang menampung semua siswa di kelas yang sama. Sekolah ini menyediakan program pendidikan yang layak, menantang, tetapi sesuai dengan kemampuan dan kebutuhan setiap siswa, maupun bantuan dan dukungan yang dapat diberikan oleh para guru agar anak-anak berhasil. Lebih dari itu, sekolah inklusi juga merupakan tempat setiap anak dapat diterima, menjadi bagian dari kelas tersebut, dan saling membantu dengan guru dan teman sebayanya, maupun anggota masyarakat lain agar kebutuhan individualnya dapat terpenuhi. Selanjutnya, Staub dan Peck menyatakan bahwa: pendidikan inklusi ${ }^{14}$ adalah penempatan anak berkelainan tingkat ringan, sedang, dan berat secara penuh di kelas reguler. Hal ini menunjukkan bahwa kelas reguler merupakan tempat belajar yang relevan bagi anak berkelainan, apapun jenis kelainannya dan bagaimanapun gradasinya. Sementara itu, Sapon-Shevin (O’Neil) menyatakan bahwa pendidikan inklusi sebagai sistem layanan pendidikan yang mempersyaratkan agar semua anak berkelainan dilayani di sekolah-sekolah terdekat, di kelas reguler bersama-sama teman seusianya. Oleh karena itu, ditekankan adanya perombakan sekolah, sehingga menjadi komunitas yang mendukung pemenuhan kebutuhan khusus setiap anak, sehingga sumber belajar menjadi memadai dan mendapat dukungan dari semua pihak, yaitu para siswa, guru, orang tua, dan masyarakat sekitarnya.Melalui pendidikan inklusi, anak berkelainan dididik bersamasama anak lainnya (normal) untuk mengoptimalkan potensi yang dimilikinya (Freiberg). Hal ini dilandasi oleh kenyataan bahwa di dalam masyarakat terdapat anak normal dan anak berkelainan

\footnotetext{
13

http://www.bintangbangsaku.com/content/prinsipprinsip-pembelajaran-di-sekolah-inklusi-tuna-laras 14

http://www.bintangbangsaku.com/content/prinsipprinsip-pembelajaran-di-sekolah-inklusi-tuna-laras
} 
yang tidak dapat dipisahkan sebagai suatu komunitas. Dalam hal ini, ada empat strategi pokok yang diterapkan pemerintah, yaitu: peraturan perundang-undangan yang menyatakan jaminan kepada setiap warga negara Indonesia (termasuk ABK temporer dan permanen) untuk memperoleh pelayanan pendidikan, memasukkan aspek fleksibilitas dan aksesibilitas ke dalam sistem pendidikan pada jalur formal, nonformal, dan informal. Selain itu, menerapkan pendidikan berbasis teknologi informasi dan komunikasi (TIK) dan mengoptimalkan peranan guru.

Di bawah ini beberapa strategi pembelajaran bagi anak berkebutuhan khusus:

\section{Strategi pembelajaran bagi anak tunanetra}

Strategi pembelajaran pada dasarnya adalah pendayagunaan secara tepat dan optimal dari semua komponen yang terlibat dalam proses pembelajaran yang meliputi tujuan, materi pelajaran, media, metode, siswa, guru, lingkungan belajar dan evaluasi sehingga proses pembelajaran berjalan dengan efektif dan efesien. Beberapa hal yang dapat dijadikan sebagai bahan pertimbangan dalam menentukan strategi pembelajaran , antara lain:

Berdasarkan pengolahan pesan terdapat dua strategi yaitu strategi pembelajaran deduktif dan induktf.

1. Berdasarkan pihak pengolah pesan yaitu strategi pembelajaran ekspositorik dan heuristic.

2. Berdasarkan pengaturan guru yaitu strategi pembelajaran dengan seorang guru dan beregu.

3. Berdasarkan jumlah siswa yaitu strategi klasikal, kelompok kecil dan individual.

4. Beradsarkan interaksi guru dan siswa yaitu strategi tatap muka, dan melalui media.

Selain strategi yang telah disebutkan di atas, ada strategi lain yang dapat diterapkan yaitu strategi individualisasi, kooperatif dan modifikasi perilaku.

\section{Strategi pembelajaran bagi anak berbakat}

Strategi pembelajaran yang sesuai denagan kebutuhan anak berbakat akan mendorong anak tersebut untuk berprestasi. Hal-hal yang harus diperhatikan dalam meneentukan strategi pembelajaran adalah :

1. Pembelajaran harus diwarnai dengan kecepatan dan tingkat kompleksitas.

2. Tidak hanya mengembangkan kecerdasan intelektual semata tetapi juga mengembangkan kecerdasan emosional.

3. Berorientasi pada modifikasi proses, content dan produk.

Model-model layanan yang bisa diberikan pada anak berbakat yaitu model layanan perkembangan kognitifafektif, nilai, moral, kreativitas dan bidang khusus.

\section{Strategi pembelajaran bagi anak tunagrahita}

Strtegi pembelajaran anak tunagrahita ringan yang belajar di sekolah umum akan berbeda dengan strategi anak tunagrahita yang belajar di sekolah luar biasa. Strategi yang dapat digunakan dalam mengajar anak tunagrahita antara lain;
1. Strategi pembelajaran yang diindividualisasikan
2. Strategi kooperatif
3. Strategi modifikasi tingkah laku

\section{Strategi pembelajaran bagi anak tunadaksa}

Strategi yang bias diterapkan bagi anak tunadaksa yaitu melalui pengorganisasian tempat pendidikan, sebagai berikut:

1. Pendidikan integrasi (terpadu)

2. Pendidikan segresi (terpisah)

3. Penataan lingkungan belajar 


\section{Strategi pembelajaran bagi anak tunalaras}

Untuk memberikan layanan kepada anak tunalaras, Kauffman mengemukakan model-model pendekatan sebagai berikut;

1. Model biogenetic

2. Model behavioral/tingkah laku

3. Model psikodinamika

4. Model ekologis

6. Strategi pembelajaran bagi anak dengan kesulitan belajar

Anak berkesulitan belajar membaca yaitu melalui program delivery dan remedial teaching

1. Anak berkesulitan belajar menulis yaitu melalui remedial sesuai dengan tingkat kesalahan.

2. Anak berkesulitan belajar berhitung yaitu melalui program remidi yang sistematis sesuai dengan urutan dari tingkat konkret, semi konkret dan tingkat abstrak.

\section{Strategi pembelajaran bagi anak tunarungu}

Strategi yang biasa digunakan untuk anak tunarungu antara lain: strategi deduktif, induktif, heuristic, ekspositorik, klasikal, kelompok, individual, kooperatif dan modifikasi perilaku.

\section{METODOLOGI PENELITIAN}

\section{A. Sumber Data}

Adapun sumber data penelitian ini adalah :

1. Kepala sekolah beserta dewan guru

2. Para Orang Tua Siswa

\section{B. Teknik Pengumpulan Data}

Dalam penelitian ini penulis menggunakan beberapa teknik, antara lain :

1. Observasi. Penulis melakukan observasi langsung ke sekolah SLB
PKK Sukarame Bandar Lampung untuk mendapatkan gambaran konkrit tentang pelaksanaan metode mengajar yang dilakukan di SLB Sukarame Bandar Lampung.

2. Wawancara. Dalam wawancara ini, penulis langsung melakukan wawancara dengan bapak Drs. Endin kepala sekolah SLB PKK, Informasi yang diperoleh dari kepala sekolah adalah mengenai informasi tentang sekolah dan strategi pembelajaran bagi anak berkebutuhan khusus yang diterapkan di sekolah ini. Wawancara juga penulis lakukan dengan beberapa orang guru dan wali murid.

3. Dokumentasi. Penulis memperoleh data melalui sumber-sumber tertulis yang utamanya adalah dokumen sekolah.

\section{Teknik Analisis Data}

Analisis data penulis peroleh melalui observasi dan wawancara kemudian diedit yang selanjutnya disimpulkan. Setelah dipelajari, data tersebut direduksi dengan cara membuat abstraksi dan diedit serta dipindahkan jawaban responden dalam tabulasi dan disusun secara rinci.

\section{TEMUAN}

Informasi yang berhasil penulis himpun saat observasi dan interview dengan kepala sekolah, guru dan wali siswa mengenai SLB PKK Sukarame Bandar Lampung adalah:

Visi :

Sekolah luar biasa SLB siap membentuk insan yang terampil berkarya guna, hidup layak di masyarakat sesuai dengan kemampuan yang dimiliki

Misi:

1. Pengembangan dan melaksanakan proses pembe-lajaran yang berkualitas. 
2. Mengupayakan kegiatan pembelajaran yang inovatif dan memotifasi semangat belajar

3. Melaksanakan pendidikan yang mengarah pada kemampuan siswa

4. Menyiapkan peserta didik untuk mempunyai keterampilan yang sederhana tapi bermanfaat

5. Menyiapkan siswa untuk menjadi warga negara yang beriman, berbudaya kreatif dan produktif

6. Menyiapkan siswa untuk melanjutkan pendidikan yang lebih tinggi

7. Meningkatkan kepedulian dan memperluas jejaring dan layanan pendidikan khusus

Data Guru :

1. Guru : SD berjumlah : 23 orang

2. Guru SMP : 6 orang dan

3. Guru SMA berjumlah : 6 orang.

Siswa yang ditampung ada dua kategori : 1. Tuna rungu 2.Tuna grahita : keterbelakangan mental, jumlah siswa saat diadakan penelitian ini minggu pertama september 2013 siswa SLB PKK Bandar Lampung, untuk SD berjumlah 153 orang, dan siswa SMP berjumlah 64 orang, dan SMA berjumlah 34 orang.

Materi pelajaran :

a. Akademik dan Mata pelajaran khusus : Bina komunikasi bunyi dan irama $30 \%$

b. Pengembangan diri $70 \%$ berupa :Tata boga, Pertukangan, dan otomotif.

Sumbangan SPP:

1. siswa SD sejumlah Rp.15.000,-

2. siswa SMP sejumlah Rp.17.000,-

3. SMA sejumlah Rp.20.000,-

Kekurangan :

- alat bantu dengar

- pandangan masyarakat

Peluang kerja sama yang bisa dikembangkan dengan IAIN adalah terbukanya kesempatan mahasiswa bisa praktek mengajar di SLB, dan selama ini belum pernah ada.

\section{PENUTUP}

\section{A. Simpulan}

Anak Berkebutuhan Khusus (ABK) merupakan istilah lain untuk menggantikan kata "Anak Luar Biasa (ALB)" yang menandakan adanya kelainan khusus. Anak berkebutuhan khusus mempunyai karakteristik yang berbeda antara yang satu dengan yang lainnya. Karena karakteristik dan hambatan yang dimilki, $\mathrm{ABK}$ memerlukan bentuk pelayanan pendidikan khusus yang disesuaikan dengan kemampuan dan potensi mereka. Bisa dikatakan Anak berkebutuhan khusus (ABK) adalah : mereka yang memiliki kelainan fisik, emosional, mental, intelektual, dan/atau sosial, baik dalam tingkat keterbatasan maupun kelebihan.

Pendidikan bagi $\mathrm{ABK}$ tergolong dalam jenis pendidikan khusus, jalur pendidikan formal, jenjang PAUD, Pendidikan Dasar, dan Pendidikan Menengah.

Pembelajaran diberikan secara indifidual yang dikelompokan atas dasar kelas sesuai bagian ketunaannya. Dengan tenaga guru Pendidikan khusus terdiri dari guru khusus berijasah S1 PK/PLB dan S1 Matapelajaran.

\section{B. Saran}

1. Demi suksenya perluasan dan pemerataan pelayanan pendidikan bagi ABK di SLB PKK Bandar Lampung, penulis menyarankan agar pihak sekolah berupaya pro aktif mensosialisasikan keberadaan pendidikan khusus ini kepada masyarakat, mengingat masih terdapat $\mathrm{ABK}$ yang belum dimasukan ke sekolah formal.

2. Diharapkan perhatian pemerintah memajukan pendidikan anak berkebutuhan khusus ini, terutama perhatian dari segi fasilitas pendidikan seperti alat bantu dengar yang dikeluhkan oleh kepala sekolah 
masih minim dan tidak memadai untuk semua murid.

\section{DAFTAR PUSTAKA}

Delphie, Bandi, Pembelajaran Anak Berkebutuhan Khusus. Bandung: Refika Aditama, 2006

Abdurrahman, Mulyono, Pendidikan Bagi Anak Berkesulitan Belajar. Jakarta: Rineka Cipta, 1999

Delphie, Bandi, Pembelajaran Anak Tunagrahita. Bandung: Refika Aditama, 2006

Hamalik, Oemar, Proses Belajar Mengajar. Jakarta: Bumi Aksara, 2007

Kauffman dan Hallahan. Hand Book of Special Education, New York: Routledge, 2005
Skjorten, MD, Towards Inclusion, Education-Special Needs Education An Introduction.Oslo: Unipub forlag, 2001

Santrock, John W, Live-Span Development.Sixth Edition. USA. Brow \& Benchmark Publisher. 1997

Skjorten, MD, Towards Inclusion and Enrichment, Artikel in Johnsen. Oslo: Unipub forlag, 2001

Wardani, I.G.A.K, Pengantar Pendidikan Luar Biasa. Jakarta: Universitas Terbuka, 2007 
